\title{
The importance of termites (Isoptera) for the recycling of herbivore dung in tropical ecosystems: a review
}

\author{
BERND P. FREYMANN ${ }^{1}$, RoBert BUITENWERF ${ }^{1}$, Og DESOUZA $^{2}$ and HAN OLFF ${ }^{1}$ \\ ${ }^{1}$ Centre for Ecological and Evolutionary Studies, Community and Conservation Ecology Group, University of Groningen, \\ PO Box 14, 9750 AA Haren, The Netherlands; e-mail: b.freymann@rug.nl \\ ${ }^{2}$ Departamento de Biologia Animal, Laboratório de Termitologia, Universidade Federal de Viçosa, 36570-000 Viçosa, MG, Brazil
}

Key words. Isoptera, comminution, decomposition, food preference, foraging, herbivores, mammalian dung, nutrient cycling, removal rates, termites

\begin{abstract}
While the key role of termites in the decomposition of litter in the tropics has been acknowledged for a long time, much less information exists on their importance in the recycling of dung of primary consumers, especially herbivores. A review of published studies shows that a diverse group of termites (at least 126 species) has been reported to feed on a wide range of mammalian dung (18 species). Predominantly, wood-feeding and polyphagous wood-litter feeding species were found to feed also frequently on dung. Moreover, we found that termites can quickly remove large amounts of mammalian dung, especially in the dry season, when on average about $1 / 3$ of the dung deposited in a given habitat is removed by termites within one month (with the highest rates observed in savannas). No distinctive preference for mammalian dung over other organic food sources was observed for fungusgrowing termites (Macrotermitinae), whereas the majority of the non-fungus growing taxa studied prefer dung over other food. As termites bring large quantities of dung below the soil surface, disturb and enrich soils with nutrients, dung feeding by termites appears to be a previously underestimated process important in the functioning of tropical ecosystems.
\end{abstract}

\section{INTRODUCTION}

Termites are widely distributed throughout the tropical and subtropical regions of the world, with the highest diversity found in tropical forests (Eggleton, 2000). By the early 1970's approximately 1900 living and fossil species of termites had been described (Lee \& Wood, 1971) and a constant flow of first descriptions is still increasing this number significantly. Termites (taxondependent) act as herbivores as well as decomposers, feeding on a wide range of living, dead or decaying plant material (Adamson, 1943; Noirot \& Noirot-Timothée, 1969; Lee \& Wood, 1971; Wood, 1976, 1978; Bignell \& Eggleton, 2000; Traniello \& Leuthold, 2000), including the consumption and turnover of large volumes of soil rich in organic matter and fungi. These feeding habits make termites important ecosystem engineers, which over long periods of time can modify the physical properties of soil such as texture, water infiltration rates and nutrient content, at various spatial scales (e.g. Dangerfield et al., 1998).

Previous overviews of the food and feeding habits of termites either only list mammalian dung as just one possible food item (Lee \& Wood, 1971; Wood, 1976, 1978; Bignell \& Eggleton, 2000; Traniello \& Leuthold, 2000) or even do not mention mammalian dung (Adamson, 1943; Noirot \& Noirot-Timothée, 1969). Only one old paper focuses on the utilization of mammalian dung by termites (Ferrar \& Watson, 1970), but it is restricted to data from the Australian region. It does not include the more recent work on the subject, and does not address the ecosystem consequences of dung feeding by termites
(Ferrar \& Watson, 1970). The lack of studies on the role of termites as dung feeders is in strong contrast to the many on the role of dung beetles in the comminution and decomposition of herbivore dung, especially their importance in nutrient cycling (reviewed in Hanski \& Cambefort, 1991). So far, the question to what extent and which species of termites consume mammalian dung and whether termites might fulfil a similar ecosystem role as dung beetles, has remained largely unanswered. In this paper we therefore review the existing literature on the processing of herbivore dung by termites, from both a termite autecological perspective, as well as its ecosystem consequences.

\section{THE AUTECOLOGICAL PERSPECTIVE}

\section{Consumption of mammalian dung}

We identified 24 studies, published between 1955 and 2004 that contain detailed data on the consumption of mammalian dung by termites (Appendix). These studies report in total 126 taxa of termites feeding on dung. This number represents a conservative count and is most likely an underestimate: studies reporting that a termite genus utilizes dung with no species specification were counted only once and omitted completely from the count if another publication provided a species-specific record for the same genus. Representatives of the families Mastotermitidae, Rhinotermitidae and predominantly Termitidae feed on dung. In our list the genus Amitermes, family Termitidae, is remarkable, in that at least 35 species are reported to use dung as a food source. This observation might be explained by the high diversity (Scheffrahn et 
al., 1999) as well as the polyphagy and tropicopolitan distribution of this genus (Eggleton, 2000), which is most diverse in semi-arid habitats (Scheffrahn \& Su, 1987).

The majority of the records were in surveys of termite diversity, a few field (using mostly cattle-dung/cattlemanure, exceptionally elephant dung) and one laboratory study, which provided only descriptive data (Skaife, 1955). There are reports of termites foraging for mammalian dung from around the globe: Africa, Asia, Australia and North-/Central-/South-America. Most observations were made in Australia and Africa, potentially mirroring a skewed emphasis on the feeding habits of termites living in grass- and bush-lands on these continents.

These studies reveal that termites feed on the dung of a total 18 mammalian species: black rhinoceros (Diceros bicornis), African buffalo (Syncerus caffer), cattle (Bos taurus), camel (Camelus sp.), dikdik (Madoqua sp.), donkey (Equus asinus asinus), African elephant (Loxodonta africana), goat (Capra aegagrus hircus), horse (Equus caballus), hyrax (Hyracoidea), impala (Aepyceros melampus), kudu (Tragelaphus sp.), kangaroo/wallaby (Macropodidae), sheep (Ovis aries), duiker (Cephalophinae), springbok (Antidorcas marsupialis), wombat (Vombatidae) and zebra (Equus quagga ssp). There are no references to a particular termite species feeding mainly on the dung of one particular mammalian herbivore species. An analysis of the collective records indicates that predominantly wood-feeding (42 species $=39 \%$ ) as well as polyphagous wood-litter feeding termite species $(27=$ $25 \%$ ) also feed on mammalian dung. In comparison, 17 litter $(=16 \%)$ and $22(=20 \%)$ soil-feeding termite species show the same behaviour. This consumption of mammalian dung by termites is of more than incidental importance. This provokes the question, how do termites manage to locate this food source which is spatially and temporally heterogeneously distributed?

\section{Locating dung}

Johnson \& Whitford (1975) studied the foraging behaviour of unidentified subterranean termites in the Chihuahuan desert and found that Yucca elata logs and cattle dung, which have a large surface area in contact with the soil, were preferred over small twigs and surface litter. They conclude that the modified environment under a large object on the soil surface (e.g. increased moisture content) is a necessary factor in food suitability, at least for subterranean termites. Ettershank et al. (1980) used baits in the field to see if this modified environment is also used to locate the food. They conclude that desert subterranean termites locate relatively large objects on the surface, such as cattle dung and Yucca sp. logs, by sensing the thermal shadows cast by such items. However, is dung particularly attractive to termites from a nutritional perspective, or just an accumulation of organic matter?

\section{Nutrition}

As Higashi et al. (1992) outline, termites generally feed on dead plant material that has a carbon to nitrogen ratio much higher than their own tissues and have to balance their $\mathrm{C}$ and $\mathrm{N}$ inputs. The same authors list two classes of such $\mathrm{C}-\mathrm{N}$ balancing mechanisms: adding $\mathrm{N}$ to inputs or selectively eliminating $\mathrm{C}$, both achieved with the aid of microbial symbionts. But the lower the $\mathrm{C} / \mathrm{N}$ ratio of the diet, the less urgent this balancing. Matsumoto (1976) reports $\mathrm{C} / \mathrm{N}$ ratios of 4 to 12 for termite tissues, whereas fresh dead wood has $\mathrm{C} / \mathrm{N}$ ratios as high as 350 to 1000 (LaFage \& Nutting, 1978). For comparison, Ouédraogo et al. (2004) provide data on the $\mathrm{C} / \mathrm{N}$ ratio of the baits they presented to termites: Andropogon straw $=153(0.32 \%$ $\mathrm{N})$, cattle dung $=40(0.95 \% \mathrm{~N})$, maize straw $=59(0.77 \%$ $\mathrm{N})$. Thus, the cattle dung provided to the termites in this study has a much more favourable $\mathrm{C} / \mathrm{N}$ ratio than the alternative food items and might, therefore, be attractive to termites. In spite of this, and the clearly high phosphorous levels in cattle dung $(1.06 \%$ vs. $0.03 \%$ in Andropogon straw and $0.18 \%$ in maize straw), the soil macrofauna preferentially removed the straw (Table 2, later discussion). This may mean that the symbiotic opportunities available to termites to compensate for very low food quality simply overrule the need to be highly selective in terms of the $\mathrm{C} / \mathrm{N}$ ratio of food. Despite the various biochemical processes involved, this may accordingly hold true for both - endo- and ectosymbiotic (fungus-growing) termites.

Alternatively, or additionally, the physical parameters bulk density, texture and spatial location of dung might make this food source attractive to termites. Compared to the alternatives, such as standing dead grass, dung pats are an easily available local accumulation of litter and organic matter, aggregated by large herbivores. Termites might simply benefit energetically by exploiting dung pats with a high mass per volume ratio, instead of feeding on grass litter that needs to be collected over a wider spatial range and in a more unfavourable microclimate. Moreover, the mammalian herbivores and their endosymbionts mechanically (fragmentation) and biochemically "preprocess" the plant materials and in this way may facilitate the further utilization by termites.

\section{THE ECOSYSTEM PERSPECTIVE}

Dung deposited naturally on the soil surface by mammalian herbivores needs to be broken down and eventually incorporated into the soil layer as part of nutrient cycling. It was suggested some time ago (e.g. Adamson, 1943) that termites have an important role in maintaining the fertility of tropical soils and the productivity of ecosystems. In addition, termites promote aeration, drainage and penetration of roots, as well as contribute to pedoturbation via their epigeal lifestyle, accelerate the formation of humus and the cycling of mineral elements by consuming dead wood and other plant remains (Adamson, 1943). The question arises, whether the comminution of mammalian dung by termites is not only of autecological importance but also affects the functioning of the ecosystem, i.e. nutrient cycling, and if so how these effects may be described and quantified. 
TABLE 1. Dung removal rates of termites measured in field experiments. Standardized removal rates were computed assuming a linear removal-time relation as e.g. found by Coe (1970). Abbreviations: $\mathrm{d}$ - days, $\mathrm{m}$ - months.

\begin{tabular}{|c|c|c|c|}
\hline Original removal rate & System & $\begin{array}{l}\text { Standardized removal rate } \\
\text { (\% dung removed/month) }\end{array}$ & Reference \\
\hline $100 \% / 80-85 \mathrm{~d}$ & $\begin{array}{l}\text { savanna, Kenya } \\
\text { dry season } \\
\text { elephant dung } \\
\text { Odontotermes sp. } \\
\text { Microtermes sp. }\end{array}$ & ca. $36 \% / \mathrm{m}$ & Coe, 1977 \\
\hline $80-85 \%$ / 5-9 m & $\begin{array}{l}\text { pasture, Costa Rica } \\
\text { dry + wet season } \\
\text { cattle dung } \\
\text { Amitermes beaumontii } \\
\text { Hoplotermes sp. } \mathrm{n} .\end{array}$ & ca. $12 \% / \mathrm{m}$ & Herrick \& Lal, 1996 \\
\hline $\begin{array}{l}80 \% / 42 \text { d (dry) } \\
50 \% / 42 \text { d (wet) }\end{array}$ & $\begin{array}{c}\text { derived savanna, Nigeria } \\
\text { dry }+ \text { wet season } \\
\text { cattle dung } \\
\text { unknown termite sp. }\end{array}$ & $\begin{array}{l}\text { ca. } 57 \% / \mathrm{m} \\
\text { (dry) } \\
\text { ca. } 36 \% / \mathrm{m} \\
\text { (wet) }\end{array}$ & Omaliko, 1981 \\
\hline $92 \% / 3 \mathrm{~m}$ & $\begin{array}{l}\text { sorghum field, Burkina Faso } \\
\text { wet season } \\
\text { cattle dung } \\
\text { Macrotermes } \mathrm{sp} . \\
\text { Trinervitermes } \mathrm{sp} .\end{array}$ & ca. $31 \% / \mathrm{m}$ & Ouédraogo et al., 2004 \\
\hline $42.2 \% / 31 / 2 \mathrm{~m}$ & $\begin{array}{c}\text { Chihuahuan desert, USA } \\
\text { cattle dung } \\
\text { Gnathamitermes tubiformans } \\
\text { Amitermes wheeleri }\end{array}$ & ca. $12 \% / \mathrm{m}$ & Whitford et al., 1982 \\
\hline
\end{tabular}

\section{Removal rates}

The results of five studies reporting the dung removal rates of termites in the field are summarized in Table 1. Since the removal rates, as reported in the original publications, were measured over different time intervals, we standardized them to: \% dung removed/month. The five studies report that termites removed between $12-57 \%$ of available dung within one month. Overall, higher removal rates were measured in the dry than in the wet season (Coe, 1977; Omaliko, 1981; Whitford et al., 1982; Ouédraogo et al., 2004). Removal rates were 12\% / month for a desert, 36-57\% / month in savannas, 31\% / month in an agricultural field and $12 \%$ / month in a pasture. Despite the low sample size, savannas tend to have the highest removal rates. Over all, the average dung removal rate by termites in these field studies was around $30 \%$ per month.

\section{Preferences and seasonality}

Another important aspect is the occurrence of food preferences and the different roles, of termites and dung beetles. The quantitative results shown in Table 1 also reflect a general qualitative trend: higher removal rates are found during the dry season in each habitat. As mentioned earlier, Ferrar \& Watson (1970) also concluded that termites prefer dry dung pats. A single study (Herrick \& Lal, 1996) documents an increased comminution of cattle dung by Amitermes beaumonti and Hoplotermes sp. n. in a Neotropical pasture ecosystem in the wet season. Many authors, e.g. Weir (1971), report that dung beetles are responsible for the removal and burial of almost all dung during the wet season. This has led various authors to state that dung beetles are generally responsible for nutrient recycling from dung (e.g. Losey \& Vaughan, 2006). It appears that this is, however, only true for the wet season: since adult dung beetles feed exclusively on the liquid component of the dung by means of specialized filtering mouthparts (Holter, 2000), they rely on the availability of dung with a high water content. In addition, some dung beetle species (e.g. Onthophagus binodis) produce significantly fewer brood balls when the soil is dry (Barkhouse \& Ridsdill-Smith, 1986). This means that in the dry season termites seem to gain in importance relative to dung beetles. But dung is not only temporally but also spatially a very heterogeneous resource; it is not permanently available to termites, because of the mobile lifestyle of its producers, while termites are sessile and bound to their nests. In contrast dung beetles are mobile and able to follow the producers. These factors might account for the food-preferences (dung vs. other natural items) of termites (Table 2). Overall, termites show no clear, distinct preference for mammalian dung over other plant food items.

A very interesting pattern is revealed if the 12 fungusgrowing taxa (Macrotermitinae) are compared with the remaining ten species that do not grow fungi: while half of the Macrotermitinae taxa show a preference for alternative plant food items $(50 \%)$, or no clear preference at all $(33 \%)$, the greater part $(70 \%)$ of the non-fungusgrowers prefer dung (Table 2). The finding regarding the fungus-growers is surprising, given the apparent advantageous nutritional characteristics of dung. Feeding on mammalian dung, however, might be even disadvantageous to a certain extent for termites, especially the Macrotermitinae: about 330 termite species in this sub- 
TABLE 2. Food preferences of termites with respect to the consumption of mammalian dung. Abbreviations: ca - cattle dung, el elephant dung, ho - horse dung, to - tortoise droppings, $\mathrm{M}$ - measurement taken.

\begin{tabular}{|c|c|c|}
\hline Food preference & Species & Reference \\
\hline $\begin{array}{l}\text { grass }=\text { ground wood }>\text { el dung } \\
\text { el dung = grass } \\
\text { el dung = grass = ground wood }>\text { "other" dung } \\
\text { el dung = grass = ground wood }>\text { "other" dung } \\
\text { ground wood }>\text { el dung } \\
\text { ground wood }>\text { el dung }\end{array}$ & $\begin{array}{l}\text { Macrotermes subhyalinus } \\
\text { Odontotermes badius } \\
\text { Odontotermes zambesiensis } \\
\text { Odontotermes mediocris } \\
\text { Microtermes allaudanus } \\
\text { Synacanthotermes zanzibarensis }\end{array}$ & $\begin{array}{l}\text { Buxton, } 1981 \\
\text { M: semi-quantitative } \\
\text { (minor vs. major consumption) }\end{array}$ \\
\hline el dung $>$ litter & $\begin{array}{l}\text { Odontotermes } \mathrm{sp} . \\
\text { Microtermes } \mathrm{sp} .\end{array}$ & $\begin{array}{l}\text { Coe, } 1977 \\
\text { M: No. plots with termites }\end{array}$ \\
\hline woody litter $>$ mammalian dung & $\begin{array}{l}\text { Macrotermes michaelseni } \\
\text { Microtermes } \mathrm{sp} .\end{array}$ & $\begin{array}{l}\text { Dangerfield \& Schuurman, } 2000 \\
\text { M: descriptive }\end{array}$ \\
\hline cattle dung $>$ mesquite wood & $\begin{array}{l}\text { Gnathamitermes tubiformans } \\
\text { Amitermes wheeleri }\end{array}$ & $\begin{array}{l}\text { Ettershank et al., } 1980 \\
\text { M: No. termite } \\
\text { attack holes }\end{array}$ \\
\hline cattle dung $>$ control (litter etc.) & $\begin{array}{l}\text { Amitermes beaumonti } \\
\text { Hoplotermes sp. } \mathrm{n} .\end{array}$ & $\begin{array}{l}\text { Gould et al., } 2001 \\
\text { M: individuals/plot }\end{array}$ \\
\hline cattle dung $>$ control (litter etc.) & $\begin{array}{l}\text { Amitermes beaumonti } \\
\text { Hoplotermes } \mathrm{sp} . \mathrm{n} .\end{array}$ & $\begin{array}{l}\text { Herrick \& Lal, } 1996 \\
\text { M: termites/l of soil }\end{array}$ \\
\hline $\begin{array}{l}\text { cattle dung }>\text { litter } \\
\text { Yucca } \text { wood }>\text { litter }\end{array}$ & unknown & $\begin{array}{l}\text { Johnson \& Whitford, } 1975 \\
\text { M: foraging groups/source/ha }\end{array}$ \\
\hline Andropogon or maize straw $>$ cattle dung & $\begin{array}{l}\text { Macrotermes } \mathrm{sp} . \\
\text { Trinervitermes } \mathrm{sp} .\end{array}$ & $\begin{array}{l}\text { Ouédraogo, } 2004 \\
\text { M: individuals/bait }\end{array}$ \\
\hline $\begin{array}{l}\text { millet (canes or ground) }>\text { cattle manure } \\
\text { millet (canes) }>\text { manure }>\text { ground millet }\end{array}$ & $\begin{array}{l}\text { Macrotermes subhyalinus } \\
\text { Odontotermes nilensis }\end{array}$ & $\begin{array}{l}\text { Rouland et al., } 2003 \\
\text { M: mass of soil sheeting }\end{array}$ \\
\hline litter $($ Restionaceae $)>$ ca,el,ho,to dung & Amitermes hastatus & $\begin{array}{l}\text { Skaife, } 1955 \\
\text { M: descriptive (lab) }\end{array}$ \\
\hline
\end{tabular}

family are known to cultivate a specialized fungus, genus Termitomyces, for food (Mueller et al., 2005). The nest of a single termite species can have different, but a few, symbiotic species (Aanen et al., 2002). Since termite nests provide conditions (high humidity, stable temperature) that favour microbial growth (Roy et al., 2006), termite nests also are favourable habitats for entomopathogenic fungi and bacteria, which hypothetically could be present in herbivore dung. Social insects are known to show host-mediated behaviour such as increased grooming, increased nest cleaning, secretion of antibiotics, dispersal of infected individuals and relocation of the entire colony in order to reduce pathogen transmission (Roy et al., 2006). The finding that fungus-growing termites do not prefer herbivore dung might be a way of avoiding pathogens. From the fungal symbionts' perspective, it may be more beneficial that termites feed it the same type of organic matter (e.g. a dominant grass) throughout the year, rather than vary greatly the type of food. It is possible, that termites exploit mammalian dung opportunistically if it becomes available as a food source, but the spatial and temporal heterogeneity of the availability of this food source counteracted the evolutionary development of a distinct behavioural preference for this food source, at least in some groups of termites.

\section{Impacts on nutrient cycling}

Despite the lack of evidence that termites as a whole prefer to feed on dung, there is support for the concept that the comminution of mammalian dung by termites affects the ecosystem functioning via nutrient cycling.

Coe (1977) estimates that in the Tsavo (East) National Park (Kenya) termites remove up to $8.7 \times 10^{3} \mathrm{~kg}$ faeces per $\mathrm{km}^{2}$ per year from the surface of the soil. This results in a nitrogen turnover of about $12 \mathrm{~kg} / \mathrm{ha} /$ year based on the nitrogen content of $1.39 \%$ for fresh elephant dung reported by Anderson \& Coe (1974). This gives a quantitative measure of the role of termites in facilitating the return of nutrients to the soil after they have passed through the primary consumer (mammalian herbivores) in the nutrient cycle. Without a directly comparable estimate of the removal of dung by dung beetles, the overall, quantitative importance of this process remains elusive. Herrick \& Lal (1996) studied dung removal by termites associated with the transport of soil, both within the soil profile and to the soil surface (pedoturbation). They found a strong linear relationship between dung removal and soil accumulation at the original soil surface, with an average of $2.0 \mathrm{~g}$ of soil accumulated for every gram of dung that is removed. For their Neotropical pasture system, they give a minimum estimate of $2450 \mathrm{~kg} \mathrm{ha}^{-1}$ year $^{-1}$ of soil turnover in association with dung produced by two animal units ha ${ }^{-1}$ (Herrick \& Lal, 1996). Basappa \& Rajagopal (1990) examined the physical and chemical properties of termite modified soils in India. This revealed that the water holding capacity, $\mathrm{pH}$, organic carbon, organic matter, total nitrogen, the cation exchange capacity, as well as the exchangeable cations, like calcium, magne- 
sium, potassium and sodium, were higher in termite modified soils than in surrounding soils (Basappa \& Rajagopal, 1990). Some of these findings (e.g. regarding phosphorous) may be explained by the incorporation of organic matter and left-over dung into termite modified soil. Similar findings are also to be expected for non-dung feeding termites. Independent of the actual source of nutrients or the processes underlying the enrichment, termite modified soils are richer in nutrients; nutrients that in turn may enhance primary productivity. This second process may be temporarily delayed: Weir (1971) used radioactive $\mathrm{P}_{32}$ to study the removal of dung by termites in Zimbabwe. This author documented that termites (unknown species) consume dung, but no radioactivity was detected in the adjacent vegetation during the five months of the dry season when the measurements were made. Thus, the removal of nutrients by termites to their mounds did not result in this material becoming accessible to plants during the dry season (Weir, 1971). This event might be delayed until a termite colony dies and the mound or nest is eventually subject to erosion; e.g. shown by Coventry et al. (1988).

Furthermore, studies document that the consumption of mammalian dung influences the spatial distribution of termites. Gould et al. (2001) found Amitermes beaumonti to be more abundant in the stratum ranging from $0-3.5 \mathrm{~cm}$ below the cattle dung baits they used in Costa Rica (vs. the $3.5-7.0 \mathrm{~cm}$ stratum). Exactly the opposite pattern was found in control areas, indicating that at least this termite species adjusts its subterranean foraging behaviour according to the accessibility of dung. From the mammalian perspective, Coe \& Carr (1978) report that blesboks (Damaliscus dorcas phillipsi) appear to deliberately place their middens in the vicinity of mounds of harvester termites (Trinervitermes trinervoides). They hypothesize that this is due either to the fact that termite mounds provide a spot of bare ground and therefore increased visibility for detecting predators and/or that blesboks are attracted to the mounds due to the increased foraging quality of the surrounding vegetation. The latter reasoning indicates this could constitute a positive feedback loop involving foraging behaviour of termites and mammalian herbivores, but this needs further clarification.

With respect to the overall nutrient cycling, termites may be seen as the crucial connective component between the dung producing herbivores and microbial decomposers in savannas by further fragmenting, and maybe even more important, spatially redistributing the dung particles. From temperate regions it is known that invertebrates, such as earthworms, are of critical importance: they comminute and ingest the plant debris, resulting in the incorporation of organic matter into the soil, as well as significantly increasing its surface area, but changing it little chemically (Burges, 1967). If herbivore dung is regarded as partially decomposed plant material, it becomes apparent that termites and earthworms fulfil comparable ecological roles in these ecosystem dynamics. The major difference between termites and other invertebrate decomposers is that, especially in savannas, consid- erable quantities of plant materials are consumed by wood-, grass- and fresh litter-feeding termites before and not after it has been attacked by saprophytic microorganisms (Wood, 1976). In the case of herbivore dung, this distinction does not hold anymore, since the plant material already has been attacked by the herbivores' own gut-endosymbionts. In contrast to the equivalent feeding guild of earthworms in temperate regions though, moundbuilding, fungus-growing termites (e.g. Macrotermes) are capable of engineering their own soil microclimate in order to facilitate the decomposition of plant materials by their symbiotic fungi.

\section{CONCLUDING REMARKS}

From an autecological point of view, we found a previously underestimated diversity of termite taxa feeding on a wide range of mammalian dung.

From the ecosystem perspective, we conclude that termites remove substantial quantities of mammalian dung and associated soil, over a relatively short period mainly in the dry season. The foraging on dung appears to be of only opportunistic importance to termites. No distinctive preference for mammalian dung could be detected for termites as a whole and for fungus-growers in particular, but was found for non-fungus-growing termites. By removing large quantities of dung from above to below the soil surface, by being responsible for substantial pedoturbation and nutrient enrichment of soils as well as by causing changes in the spatial distribution of termites and even the mammalian dung producers themselves, this feeding behaviour appears to be of great importance at the ecosystem level.

Coming back to our initial question whether termites, by foraging on mammalian dung, might fulfil a comparable ecological role to dung beetles in the context of nutrient cycling, we conclude that the current body of literature supports qualitatively the view that these two feeding guilds are both of ecological significance, but insufficient, quantitative information exists to definitely answer this question at this point in time.

ACKNOWLEDGEMENTS. B.P.F. is grateful to S.N. de Visser for support and encouragement. We thank S.N. de Visser and three anonymous reviewers for very helpful comments on earlier versions of the manuscript. B.P.F. and H.O. were financially supported by the Robert Bosch Foundation (Germany) as well as by the Netherlands Organization for Scientific Research.

\section{REFERENCES}

Aanen D.K., Eggleton P., Rouland-Lefèvre C., GuldbergFrøslev T., Rosendahl S. \& Boomsma J.J. 2002: The evolution of fungus-growing termites and their mutualistic symbionts. PNAS 99: 14887-14892.

Adamson A.M. 1943: Termites and the fertility of soils. Trop. Agric. 20: 107-112.

Anderson J.M. \& CoE M.J. 1974: Decomposition of elephant dung in an arid, tropical environment. Oecologia 14: 111-125.

Araujo R.L. 1970: Termites of the Neotropical region. In Krishna K. \& Weesner F.M. (eds): Biology of Termites. Vol 2. Academic Press, New York, London, pp. 527-576. 
Barkhouse J. \& RidSDILl-SMith T.J. 1986: Effect of soil moisture on brood ball production by Onthophagus binodis Thunberg and Euoniticellus intermedius (Reiche) (Coleoptera: Scarabaeinae). J. Aust. Entomol. Soc. 25: 75-78.

Basappa H. \& Rajagopal D. 1990: Physico-chemical properties of termite modified soils due to foraging on dung in comparison with surrounding soils. Sociobiology 16: 275-284.

Bignell D.E. \& Eggleton P. 2000: Termites in ecosystems. In Abe T., Bignell D.E. \& Higashi M. (eds): Termites: Evolution, Sociality, Symbioses, Ecology. Kluwer Academic Publications, Dordrecht, pp. 363-387.

BURCHARD I. 1989: On the removal of herbivore dung by Odontotermes spp. in Africa. Sociobiology 15: 261.

Burges A. 1967: The decomposition of organic matter in the soil. In Burges A. \& Raw F. (eds): Soil Biology. Academic Press, New York, London, pp. 479-492.

BuXTON R.D. 1981: Changes in the composition and activities of termite communities in relation to changing rainfall. Oecologia 51: 371-378.

COATON W.G.H. \& Sheasby J.L. 1972: Preliminary report on a survey of the termites (Isoptera) of South West Africa. Cimbebasia Memoir No. 2, 129 pp.

COE M. 1977: The role of termites in the removal of elephant dung in the Tsavo (East) National Park Kenya. E. Afr. Wildl. J. 15: 49-55.

CoE M. \& CARR R.D. 1978: The association between dung middens of the blesbok (Damaliscu dorcas philipsi Harper) and mounds of the harvester termite (Trinervitermes trinervoides Sjoestedt). S. Afr. J. Wildl. Res. 8: 65-69.

Constantino R. \& DeSouza O. 1997: Key to soldiers of Atlantitermes Fontes, with a new species from Brazil (Isoptera: Termitidae: Nasutitermitinae). Trop. Zool. 10: 205-213.

Coventry R.J., Holt J.A. \& Sinclair D.F. 1988: Nutrient cycling by mound-building termites in low-fertility soils of semi-arid tropical Australia. Aust. J. Soil Res. 26: 375-390.

Dangerfield J.M., McCarthy T.S. \& Ellery W.N. 1998: The mound-building termite Macrotermes michaelseni as an ecosystem engineer. J. Trop. Ecol. 14: 507-520.

Dangerfield J.M. \& SchuUrman G. 2000: Foraging by fungusgrowing termites (Isoptera: Termitidae, Macrotermitinae) in the Okavango Delta, Botswana. J. Trop. Ecol. 16: 717-731.

DeSouzA O. 1993: Effects of Habitat Fragmentation on Termites in Cerrado. PhD thesis, University of London, London, $124 \mathrm{pp}$.

EgGLeton P. 2000: Global patterns of termite diversity. In Abe T., Bignell D.E. \& Higashi M. (eds): Termites: Evolution, Sociality, Symbioses, Ecology. Kluwer, Dordrecht, pp. 25-51.

EtTershank G., EtTERSHANK J.A. \& Whitford W.G. 1980: Location of food sources by subterranean termites. Environ. Entomol. 9: 645-648.

FERRAR P. \& WATSON J.A.L. 1970: Termites (Isoptera) associated with dung in Australia. J. Aust. Entomol. Soc. 9: $100-102$.

Gay F.J. \& Calaby J.H. 1970: Termites of the Australian region. In Krishna K. \& Weesner F.M. (eds): Biology of Termites. Vol 2. Academic Press, New York, London, pp. 393-448.

Gould K.A., Herrick J.E. \& Lezama H. 2001: Refuse to refuge: dry season use and modification of cattle dung by subterranean termites in Guanacaste, Costa Rica. Biotropica 33: $121-130$

Hanski I. \& Cambefort Y. (eds) 1991: Dung Beetle Ecology. Princeton University Press, Princeton, $520 \mathrm{pp}$.

Harris W.V. 1970: Termites of the Palearctic region. In Krishna K. \& Weesner F.M. (eds): Biology of Termites. Vol 2. Academic Press, New York, London, pp. 295-313.
HERRICK J.E. \& LAL R. 1996: Dung decomposition and pedoturbation in a seasonally dry tropical pasture. Biol. Fertil. Soils 23: $177-181$.

Higashi M., Abe T. \& Burns T.P. 1992: Carbon-nitrogen balance and termite ecology. Proc. R. Soc. Lond. (B) 249: 303-308.

Holter P. 2000: Particle feeding in Aphodius dung beetles (Scarabaeidae): old hypotheses and new experimental evidence. Funct. Ecol. 14: 631-637.

JoHNSON K.A. \& WhitFord W.G. 1975: Foraging ecology and relative importance of subterranean termites in Chihuahuan desert ecosystems. Environ. Entomol. 4: 66-70.

Kemp P.B. 1955: The termites of north-eastern Tanganyika: their distribution and biology. Bull. Entomol. Res. 46: 112-135.

LAFAGE K.E. \& NutTing W.L. 1978: Nutrient dynamics of termites. In Brian M.V. (ed): Production Ecology of Ants and Termites. Cambridge University Press, Cambridge, pp. 165-232.

Lee K.E. \& Wood T.G. 1971: Termites and Soils. Academic Press, New York, London, 251 pp.

Losey J.E. \& Vaughan M. 2006: The economic value of ecological services provided by insects. BioScience 56: 311-323.

Mатsumoto T. 1976: The role of termites in an equatorial rain forest ecosystem of West Malaysia. 1. Population density, biomass, carbon, nitrogen and calorific content and respiration rate. Oecologia 22: 153-178.

Mitchell B.L. 1980: Report on a survey of the termites of Zimbabwe. Occas. Pap. Natl. Rhod. (B, Nat. Sci.) 6: 187-323.

Mueller U.G., Gerardo N.M., Aanen D.K., Six D.L. \& SCHULTZ T.R. 2005: The evolution of agriculture in insects. Annu. Rev. Ecol. Evol. Syst. 36: 563-595.

Noirot C. \& Noirot-Timothée C. 1969: The digestive system. In Krishna K. \& Weesner F.M. (eds): Biology of Termites. Vol 1. Academic Press, New York, London, pp. 49-88.

OMaLIKo C.P.E. 1981: Dung deposition, breakdown and grazing behavior of beef cattle at two seasons in a tropical grassland ecosystem. J. Range Manag. 34: 360-362.

OuÉdraogo E., Mando A. \& BrussaArd L. 2004: Soil macrofaunal-mediated organic resource disappearance in semi-arid West Africa. Appl. Soil Ecol. 27: 259-267.

Roonwal M.L. 1970: Termites of the Oriental region. In Krishna K. \& Weesner F.M. (eds): Biology of Termites. Vol 2. Academic Press, New York, London, pp. 315-391.

Rouland C., Lepage M., Chotte J.L., Diouf M., Ndiaye D., Ndiaye S., Seugé C. \& Brauman A. 2003: Experimental manipulation of termites (Isoptera, Macrotermitinae) foraging in a Sahelo-Sudanese savanna: effect of litter quality. Insectes Soc. 50: 309-316.

Roy H.E., Steinkraus D.C., Eilengerg J., Hajek A.E. \& Pell J.K. 2006: Bizarre interactions and endgames: Entomopathogenic fungi and their arthropod hosts. Annu. Rev. Entomol. 51: 331-357.

SCHEFFRAHN R.H. \& Su N.-Y. 1987: A world list of species in the genus Amitermes (Isoptera: Termitidae). Sociobiology 13: 183-190.

Scheffrahn R.H., Su N.-Y. \& Myles T.G. 1999: Amitermes amicki, a new subterranean termite (Isoptera: Termitidae: Termitinae) from Aruba. Fla Entomol. 82: 7-14.

SkaIfE S.H. 1955: Dwellers in Darkness: An Introduction to the Study of Termites. Longmans Green, London, 134 pp.

TRANIELlo J.F.A. \& LeUTHOLd R.H. 2000: Behavior and ecology of foraging in termites. In Abe T., Bignell D.E. \& Higashi M. (eds): Termites: Evolution, Sociality, Symbioses, Ecology. Kluwer, Dordrecht, pp. 141-168. 
Uys V. 2002: A Guide to the Termite Genera of Southern Africa. Plant Protection Research Institute Handbook No. 15. Agricultural Research Council, Pretoria, 116 pp.

WeESNER F.M. 1970: Termites of the Nearctic region. In Krishna K. \& Weesner F.M. (eds): Biology of Termites. Vol 2. Academic Press, New York, London, pp. 477-525.

WEIR J.S. 1971: The effect of creating additional water supplies in a Central African National Park. In Duffey E. \& Watt A.S. (eds): The Scientific Management of Animal and Plant Communities for Conservation. Blackwell Scientific Publications, Oxford, pp. 367-385.
Whitford W.G., Steinberger Y. \& Ettershank G. 1982: Contributions of subterranean termites to the "economy" of Chihuahuan desert ecosystems. Oecologia 55: 298-302.

Wood T.G. 1976: The role of termites (Isoptera) in decomposition processes. In Anderson J.M. \& Macfadyen A. (eds): The Role of Terrestrial and Aquatic Organisms in Decomposition Processes. Blackwell, Oxford, pp. 145-168.

Wood T.G. 1978: Food and feeding habits of termites. In Brian M.V. (ed): Production Ecology of Ants and Termites. Cambridge University Press, Cambridge, pp. 55-80.

Received May 22, 2007; revised and accepted January 21, 2008

APPENDIX. Termites reported to forage on dung. Dung consumed: br - black rhinoceros, bu - buffalo, ca - cattle, cam - camel, di - dikdik, do - donkey, el - elephant, em - emu, go - goat, ho - horse, hy - hyrax, im - impala, ku - kudu, kw - kangaroo/wallaby, sh - sheep, sm - small buck, sp - springbok, to - tortoise, wo - wombat, ze - zebra; Country: Au - Australia, BF - Burkina Faso, Bo - Botswana, Br - Brazil, CR - Costa Rica, In - India, Ke - Kenya, Na - Namibia, SA - South Africa, Se - Senegal, Tz - Tanzania, USA, Zi - Zimbabwe; Habitat: AF - agricultural field, Bu - bush land/wood land, De - desert, Pa - pasture, Sa - savanna; Study: Ex - experiment in field, La - laboratory, $\mathrm{Su}$ - survey; Other diet: $\mathrm{W}$ - wood-feeding, $\mathrm{L}$ - litter-feeding, $\mathrm{S}$ - soil-feeding.

\begin{tabular}{|c|c|c|c|c|c|c|}
\hline Taxon & Dung & Country & Habitat & Study & Other diet & Reference \\
\hline \multicolumn{7}{|l|}{ MASTOTERMITIDAE } \\
\hline Mastotermes darwiniensis & $\mathrm{ca}$ & $\mathrm{Au}$ & $?$ & $\mathrm{Su}$ & WL & $\begin{array}{l}\text { Ferrar \& Watson, 1970; } \\
\text { Gay \& Calaby, } 1970\end{array}$ \\
\hline \multicolumn{7}{|l|}{ RHINOTERMITIDAE } \\
\hline Heterotermes cf. tenuis & $\mathrm{ca}$ & $\mathrm{Br}$ & $\mathrm{Sa}$ & Ex & $\mathrm{W}$ & DeSouza, 1993 \\
\hline Heterotermes ferox & ca,ho & $\mathrm{Au}$ & $?$ & $\mathrm{Su}$ & $\mathrm{W}$ & Ferrar \& Watson, 1970 \\
\hline Heterotermes longiceps & $\mathrm{ca}$ & $\mathrm{Br}$ & $\mathrm{Sa}$ & Ex & $\mathrm{W}$ & DeSouza, 1993 \\
\hline Heterotermes paradoxus & ca,ho & $\mathrm{Au}$ & $?$ & $\mathrm{Su}$ & $\mathrm{W}$ & Ferrar \& Watson, 1970 \\
\hline \multirow[t]{2}{*}{ Psammotermes allocerus } & br,ca, & $\mathrm{Na}$ & $\mathrm{Bu}, \mathrm{Sa}$ & $\mathrm{Su}$ & $\mathrm{W}$ & Coaton \& Sheasby, 1972 \\
\hline & $\begin{array}{c}\text { cam,do,el, } \\
\text { go,ho,sh,sp,ze }\end{array}$ & $\mathrm{Zi}$ & $\mathrm{Bu}$ & $\mathrm{Su}$ & $\mathrm{W}$ & Mitchell, 1980 \\
\hline Psammotermes hybostoma & $?$ & $?$ & $?$ & $?$ & $?$ & Harris, 1970 \\
\hline Schedorhinotermes actuosus & $\mathrm{ca}$ & $\mathrm{Au}$ & $?$ & $\mathrm{Su}$ & WL & Ferrar \& Watson, 1970 \\
\hline Schedorhinotermes seclusus & ho & $\mathrm{Au}$ & $?$ & $\mathrm{Su}$ & $\mathrm{W}$ & Ferrar \& Watson, 1970 \\
\hline \multicolumn{7}{|l|}{ TERMITIDAE } \\
\hline Anoplotermes spp. a,b & $\mathrm{ca}$ & $\mathrm{Br}$ & $\mathrm{Sa}$ & Ex & S & DeSouza, 1993 \\
\hline Grigiotermes sp. & $\mathrm{ca}$ & $\mathrm{Br}$ & $\mathrm{Sa}$ & Ex & S & DeSouza, 1993 \\
\hline Hoplotermes sp. n. & $\mathrm{ca}$ & CR & $\mathrm{Pa}$ & Ex & $?$ & $\begin{array}{l}\text { Herrick \& Lal, 1996; } \\
\text { Gould et al., } 2001\end{array}$ \\
\hline $\begin{array}{l}\text { Ruptitermes spp. a,d } \\
\text { Macrotermitinae }\end{array}$ & $\mathrm{ca}$ & $\mathrm{Br}$ & $\mathrm{Sa}$ & Ex & S & DeSouza, 1993 \\
\hline \multirow[t]{2}{*}{ Allodontermes sp. } & ca,do, & $\mathrm{Na}$ & $\mathrm{Bu}, \mathrm{Sa}$ & $\mathrm{Su}$ & WL & Coaton \& Sheasby, 1972 \\
\hline & el,ho,ku,ze & $\mathrm{Zi}$ & $\mathrm{Bu}, \mathrm{Sa}$ & $\mathrm{Su}$ & WL & Mitchell, 1980 \\
\hline \multirow[t]{2}{*}{ Ancistrotermes latinotus } & ca,el, & $\mathrm{Zi}$ & $\mathrm{Bu}, \mathrm{Sa}$ & $\mathrm{Su}$ & WL & Mitchell, 1980 \\
\hline & $\mathrm{ku}, \mathrm{sm}$ & SA & & $\mathrm{Su}$ & & Uys, 2002 \\
\hline Macrotermes sp. & ca,el & $\mathrm{Na}$ & $\mathrm{Bu}, \mathrm{Sa}$ & $\mathrm{Su}$ & WL & Coaton \& Sheasby, 1972 \\
\hline Macrotermes sp. & ca & $\mathrm{BF}$ & $\mathrm{AF}$ & Ex & WL & Ouédraogo et al., 2004 \\
\hline Macrotermes falciger & ca,el & $\mathrm{Zi}$ & $\mathrm{Bu}, \mathrm{Sa}$ & $\mathrm{Su}$ & WL & Mitchell, 1980 \\
\hline Macrotermes michaelseni & ca,el & $\mathrm{Bo}, \mathrm{Zi}$ & $\mathrm{Bu}, \mathrm{Sa}$ & $\mathrm{Su}$ & WL & $\begin{array}{l}\text { Dangerfield \& Schuurman, } \\
\text { 2000; Mitchell, } 1980\end{array}$ \\
\hline Macrotermes subhyalinus & ca,el & $\mathrm{Ke}, \mathrm{Zi}$ & $\mathrm{Bu}, \mathrm{Sa}$ & $\mathrm{Su}$ & WL & Buxton, 1981; Mitchell, 1980 \\
\hline Macrotermes subhyalinus & ca & $\mathrm{Se}$ & $\mathrm{Sa}$ & Ex & WL & Rouland et al., 2003 \\
\hline Macrotermes ukuzii & bu,cal, & $\mathrm{Zi}$ & $\mathrm{Bu}, \mathrm{Sa}$ & $\mathrm{Su}$ & WL & Mitchell, 1980 \\
\hline \multirow[t]{4}{*}{ Microtermes sp. } & bu,ca,do, & $\mathrm{Na}$ & $\mathrm{Bu}, \mathrm{Sa}$ & $\mathrm{Su}$ & $\mathrm{W}$ & Coaton \& Sheasby, 1972 \\
\hline & el,ho, & $\mathrm{Ke}$ & $\mathrm{Bu}, \mathrm{Sa}$ & Ex & $\mathrm{W}$ & Coe, 1977 \\
\hline & $\mathrm{ku}, \mathrm{sh}$ & Bo & $\mathrm{Bu}, \mathrm{Sa}$ & $\mathrm{Su}$ & $\mathrm{W}$ & Dangerfield \& Schuurman, 2000 \\
\hline & & $\mathrm{Zi}$ & $\mathrm{Bu}, \mathrm{Sa}$ & $\mathrm{Su}$ & $\mathrm{W}$ & Mitchell, 1980 \\
\hline Microtermes allaudanus & el & $\mathrm{Ke}$ & $\mathrm{Bu}, \mathrm{Sa}$ & $\mathrm{Su}$ & $\mathrm{W}$ & Buxton, 1981 \\
\hline Odontotermes sp. & ca,do, & $\mathrm{Na}$ & $\mathrm{Bu}, \mathrm{Sa}$ & $\mathrm{Su}$ & $\mathrm{W}$ & Coaton \& Sheasby, 1972 \\
\hline
\end{tabular}




\begin{tabular}{|c|c|c|c|c|c|c|}
\hline Odontotermes amaniensis & $?$ & $\mathrm{Ke}$ & $?$ & Ex & W & Burchard, 1989 \\
\hline Odontotermes badius & ca,el & $\mathrm{Ke}, \mathrm{Zi}$ & $\mathrm{Bu}, \mathrm{Sa}$ & $\mathrm{Su}$ & $\mathrm{WL} / \mathrm{L}$ & Buxton, 1981; Mitchell, 1980 \\
\hline Odontotermes boranicus & el & $\mathrm{Tz}$ & $\mathrm{Bu}$ & $\mathrm{Su}$ & W & Kemp, 1955 \\
\hline Odontotermes horni & $?$ & In & $?$ & Ex & $?$ & Basappa \& Rajagopal, 1990 \\
\hline Odontotermes latericius & ca,el & $\mathrm{Zi}$ & $\mathrm{Bu}, \mathrm{Sa}$ & $\mathrm{Su}$ & W & Mitchell, 1980 \\
\hline Odontotermes mediocris & el & $\mathrm{Ke}$ & $\mathrm{Bu}, \mathrm{Sa}$ & $\mathrm{Su}$ & WL & Buxton, 1981 \\
\hline Odontotermes nilensis & $\mathrm{ca}$ & $\mathrm{Se}$ & $\mathrm{Sa}$ & Ex & WL & Rouland et al., 2003 \\
\hline Odontotermes obesus & $?$ & In & $?$ & Ex & $?$ & Basappa \& Rajagopal, 1990 \\
\hline Odontotermes patruus & $\mathrm{ca}$ & $\mathrm{Tz}$ & $\mathrm{Bu}$ & $\mathrm{Su}$ & W & Kemp, 1955 \\
\hline Odontotermes stercorivorus & $?$ & $\mathrm{Ke}$ & $?$ & Ex & $\mathrm{W}$ & Burchard, 1989 \\
\hline Odontotermes transvaalensis & $\mathrm{ca}$ & $\mathrm{Zi}$ & $\mathrm{Bu}, \mathrm{Sa}$ & $\mathrm{Su}$ & W & Mitchell, 1980 \\
\hline Odontotermes wallonensis & $?$ & In & $?$ & Ex & $?$ & Basappa \& Rajagopal, 1990 \\
\hline Odontotermes zambesiensis & el & $\mathrm{Ke}$ & $\mathrm{Bu}, \mathrm{Sa}$ & $\mathrm{Su}$ & WL & Buxton, 1981 \\
\hline \multirow[t]{2}{*}{ Pseudacanthotermes militaris } & $\mathrm{ca}$ & $\mathrm{Zi}$ & $\mathrm{Bu}$ & $\mathrm{Su}$ & WL & Mitchell, 1980 \\
\hline & & SA & & $\mathrm{Su}$ & & Uys, 2002 \\
\hline $\begin{array}{l}\text { Synacanthotermes zanzibarensis } \\
\text { Nasutitermitinae }\end{array}$ & el & $\mathrm{Ke}$ & $\mathrm{Bu}, \mathrm{Sa}$ & $\mathrm{Su}$ & W & Buxton, 1981 \\
\hline Armitermes spp. a,b,c & ca & $\mathrm{Br}$ & $\mathrm{Sa}$ & Ex & $\mathrm{S}$ & DeSouza, 1993 \\
\hline Atlantitermes stercophilus & $\mathrm{ca}$ & $\mathrm{Br}$ & $\mathrm{Sa}$ & Ex & S & Constantino \& DeSouza, 1997 \\
\hline Baucaliotermes hainesi & ca & $\mathrm{Na}$ & $\mathrm{Bu}, \mathrm{De}, \mathrm{Sa}$ & $\mathrm{Su}$ & $\mathrm{L}$ & Coaton \& Sheasby, 1972 \\
\hline Cornitermes sp. & $\mathrm{ca}$ & $\mathrm{Br}$ & $\mathrm{Sa}$ & Ex & $\mathrm{W}$ & DeSouza, 1993 \\
\hline Diversitermes diversimiles & $\mathrm{ca}$ & $\mathrm{Br}$ & $\mathrm{Sa}$ & Ex & W & DeSouza, 1993 \\
\hline Embiratermes heterotypus & ca & $\mathrm{Br}$ & $\mathrm{Sa}$ & Ex & $\mathrm{S}$ & DeSouza, 1993 \\
\hline Embiratermes spissus & ca & $\mathrm{Br}$ & $\mathrm{Sa}$ & Ex & $\mathrm{S}$ & DeSouza, 1993 \\
\hline \multirow[t]{2}{*}{ Fulleritermes coatoni } & ca & $\mathrm{Zi}$ & $\mathrm{Bu}, \mathrm{Sa}$ & $\mathrm{Su}$ & WL & Mitchell, 1980 \\
\hline & & SA & & $\mathrm{Su}$ & & Uys, 2002 \\
\hline Labiotermes spp. a,b & $\mathrm{ca}$ & $\mathrm{Br}$ & $\mathrm{Sa}$ & Ex & $\mathrm{S}$ & DeSouza, 1993 \\
\hline Nasutitermes coxipoensis & ca & $\mathrm{Br}$ & $\mathrm{Sa}$ & Ex & $\mathrm{W}$ & DeSouza, 1993 \\
\hline Nasutitermes eucalypti & $\mathrm{ca}$ & $\mathrm{Au}$ & $?$ & $\mathrm{Su}$ & $\mathrm{W}$ & Ferrar \& Watson, 1970 \\
\hline Nasutitermes kemneri & ca & $\mathrm{Br}$ & $\mathrm{Sa}$ & Ex & $\mathrm{W}$ & DeSouza, 1993 \\
\hline Nasutitermes kimberleyensis & $\mathrm{ca}$ & $\mathrm{Au}$ & $?$ & $\mathrm{Su}$ & $\mathrm{W}$ & Ferrar \& Watson, 1970 \\
\hline Nasutitermes longipennis & $\mathrm{ca}$ & $\mathrm{Au}$ & $?$ & $\mathrm{Su}$ & WL & Ferrar \& Watson, 1970 \\
\hline Nasutitermes torresi & ca,ho & $\mathrm{Au}$ & $?$ & $\mathrm{Su}$ & $?$ & Ferrar \& Watson, 1970 \\
\hline Paracornitermes laticephalus & $\mathrm{ca}$ & $\mathrm{Br}$ & $\mathrm{Sa}$ & Ex & S & DeSouza, 1993 \\
\hline Procornitermes sp. & $?$ & $?$ & $?$ & $?$ & $?$ & Araujo, 1970 \\
\hline Procornitermes sp. & ca & $\mathrm{Br}$ & $\mathrm{Sa}$ & Ex & $\mathrm{S}$ & DeSouza, 1993 \\
\hline Rhadinotermes coarctatus & ca & $\mathrm{Zi}$ & $\mathrm{Bu}, \mathrm{Sa}$ & $\mathrm{Su}$ & WL & Mitchell, 1980 \\
\hline Rhynchotermes nasutissimus & $\mathrm{ca}$ & $\mathrm{Br}$ & $\mathrm{Sa}$ & Ex & $\mathrm{L}$ & DeSouza, 1993 \\
\hline \multicolumn{7}{|l|}{ Rhynchotermes sp. a } \\
\hline Subulitermes sp. & $\mathrm{ca}$ & $\mathrm{Br}$ & $\mathrm{Sa}$ & Ex & S & DeSouza, 1993 \\
\hline Syntermes sp. & $\mathrm{ca}$ & $\mathrm{Br}$ & $\mathrm{Sa}$ & Ex & $\mathrm{L}$ & DeSouza, 1993 \\
\hline \multirow[t]{3}{*}{ Trinervitermes sp. } & ca,el,ho & $\mathrm{Na}$ & $\mathrm{Bu}, \mathrm{Sa}$ & $\mathrm{Su}$ & $\mathrm{L}$ & Coaton \& Sheasby, 1972 \\
\hline & $\mathrm{ca}$ & $\mathrm{Zi}$ & $\mathrm{Bu}, \mathrm{Sa}$ & $\mathrm{Su}$ & $\mathrm{L}$ & Mitchell, 1980 \\
\hline & $\mathrm{ca}$ & $\mathrm{BF}$ & $\mathrm{AF}$ & Ex & $\mathrm{L}$ & Ouédraogo et al., 2004 \\
\hline Tumulitermes comatus & $\mathrm{ca}$ & $\mathrm{Au}$ & $?$ & $\mathrm{Su}$ & WL & Ferrar \& Watson, 1970 \\
\hline Tumulitermes dalbiensis & ho & $\mathrm{Au}$ & $?$ & $\mathrm{Su}$ & $\mathrm{L}$ & Ferrar \& Watson, 1970 \\
\hline Velocitermes paucipilis & $\mathrm{ca}$ & $\mathrm{Br}$ & $\mathrm{Sa}$ & Ex & $\mathrm{L}$ & DeSouza, 1993 \\
\hline $\begin{array}{l}\text { Velocitermes spp. } 1,2, \mathrm{~g} \\
\text { Termitinae }\end{array}$ & ca & $\mathrm{Br}$ & $\mathrm{Sa}$ & Ex & $\mathrm{L}$ & DeSouza, 1993 \\
\hline \multirow[t]{2}{*}{ Amitermes sp. } & br,ca, & $\mathrm{Na}$ & $\mathrm{Bu}, \mathrm{Sa}$ & $\mathrm{Su}$ & W & Coaton \& Sheasby, 1972 \\
\hline & do,el,go,ho,sh,ze & $\mathrm{Au}$ & $?$ & $?$ & $?$ & Gay \& Calaby, 1970 \\
\hline Amitermes abruptus & ca,ho,kw,sh & $\mathrm{Au}$ & $?$ & $\mathrm{Su}$ & WL & Ferrar \& Watson, 1970 \\
\hline Amitermes agrilus & $\mathrm{ca}$ & $\mathrm{Au}$ & $?$ & $\mathrm{Su}$ & WL & Ferrar \& Watson, 1970 \\
\hline Amitermes beaumonti & ca & $\mathrm{CR}$ & $\mathrm{Pa}$ & Ex & $?$ & $\begin{array}{l}\text { Herrick \& Lal, 1996; } \\
\text { Gould et al., } 2001\end{array}$ \\
\hline Amitermes boreus & ca,ho & $\mathrm{Au}$ & $?$ & $\mathrm{Su}$ & WL & Ferrar \& Watson, 1970 \\
\hline
\end{tabular}




\begin{tabular}{|c|c|c|c|c|c|c|}
\hline Amitermes capito & $\mathrm{ca}$ & $\mathrm{Au}$ & $?$ & $\mathrm{Su}$ & W & Ferrar \& Watson, 1970 \\
\hline Amitermes colonus & ho,sh & $\mathrm{Au}$ & $?$ & $\mathrm{Su}$ & $\mathrm{W}$ & Ferrar \& Watson, 1970 \\
\hline Amitermes darwini & ca,ho,sh & $\mathrm{Au}$ & $?$ & $\mathrm{Su}$ & WL & Ferrar \& Watson, 1970 \\
\hline Amitermes dentosus & ca,ho,sh & $\mathrm{Au}$ & $?$ & $\mathrm{Su}$ & $\mathrm{W}$ & Ferrar \& Watson, 1970 \\
\hline Amitermes deplenatus & ho & $\mathrm{Au}$ & $?$ & $\mathrm{Su}$ & W & Ferrar \& Watson, 1970 \\
\hline Amitermes eucalypti & $\mathrm{ca}$ & $\mathrm{Au}$ & $?$ & $\mathrm{Su}$ & $\mathrm{W}$ & Ferrar \& Watson, 1970 \\
\hline Amitermes exilis & ca,ho & $\mathrm{Au}$ & $?$ & $\mathrm{Su}$ & W & Ferrar \& Watson, 1970 \\
\hline Amitermes germanus & ca,ho & $\mathrm{Au}$ & $?$ & $\mathrm{Su}$ & W & Ferrar \& Watson, 1970 \\
\hline Amitermes gracilis & ca & $\mathrm{Au}$ & $?$ & $\mathrm{Su}$ & $?$ & Ferrar \& Watson, 1970 \\
\hline Amitermes hartmeyeri & ca,ho,kw & $\mathrm{Au}$ & $?$ & $\mathrm{Su}$ & W & Ferrar \& Watson, 1970 \\
\hline Amitermes hastatus & ca,el,ho,to & SA & $\mathrm{Bu}, \mathrm{Sa}$ & $\mathrm{La}$ & $\mathrm{L}$ & Skaife, 1955 \\
\hline Amitermes herbertensis & ca & $\mathrm{Au}$ & $?$ & $\mathrm{Su}$ & $\mathrm{W}$ & Ferrar \& Watson, 1970 \\
\hline Amitermes heterognathus & $\mathrm{ca}$ & $\mathrm{Au}$ & $?$ & $\mathrm{Su}$ & WL & Ferrar \& Watson, 1970 \\
\hline Amitermes lanceolatus & ca,ho & $\mathrm{Au}$ & $?$ & $\mathrm{Su}$ & $\mathrm{W}$ & Ferrar \& Watson, 1970 \\
\hline Amitermes latidens & ca & $\mathrm{Au}$ & $?$ & $\mathrm{Su}$ & $\mathrm{W}$ & Ferrar \& Watson, 1970 \\
\hline Amitermes lativentris & ca,ho & $\mathrm{Au}$ & $?$ & $\mathrm{Su}$ & WL & Ferrar \& Watson, 1970 \\
\hline Amitermes laurensis & $\mathrm{ca}$ & $\mathrm{Au}$ & $?$ & $\mathrm{Su}$ & $\mathrm{L}$ & Ferrar \& Watson, 1970 \\
\hline Amitermes modicus & $\mathrm{ca}$ & $\mathrm{Au}$ & $?$ & $\mathrm{Su}$ & WL & Ferrar \& Watson, 1970 \\
\hline Amitermes neogermanus & cam,ca,ho & $\mathrm{Au}$ & $?$ & $\mathrm{Su}$ & WL & Ferrar \& Watson, 1970 \\
\hline Amitermes obtusidens & ca,ho & $\mathrm{Au}$ & $?$ & $\mathrm{Su}$ & $\mathrm{W}$ & Ferrar \& Watson, 1970 \\
\hline Amitermes perarmatus & $\mathrm{ca}, \mathrm{em}$ & $\mathrm{Au}$ & $?$ & $\mathrm{Su}$ & WL & Ferrar \& Watson, 1970 \\
\hline Amitermes sciangallorum & el & $\mathrm{Ke}$ & $\mathrm{Bu}, \mathrm{Sa}$ & $\mathrm{Su}$ & $?$ & Buxton, 1981 \\
\hline Amitermes vitiosus & ca,ho & $\mathrm{Au}$ & $?$ & $\mathrm{Su}$ & WL & Ferrar \& Watson, 1970 \\
\hline Amitermes westraliensis & $\mathrm{ca}$ & $\mathrm{Au}$ & $?$ & $\mathrm{Su}$ & WL & Ferrar \& Watson, 1970 \\
\hline Amitermes wheeleri & $\mathrm{ca}$ & USA & $\mathrm{De}$ & Ex & $\mathrm{W}$ & $\begin{array}{l}\text { Ettershank et al., } 1980 \\
\text { Whitford et al., } 1982\end{array}$ \\
\hline Amitermes xylophagus & wo & $\mathrm{Au}$ & $?$ & $\mathrm{Su}$ & W & Ferrar \& Watson, 1970 \\
\hline Amitermes spp. I-V & ca & $\mathrm{Au}$ & $?$ & $\mathrm{Su}$ & $\mathrm{L}$ & Ferrar \& Watson, 1970 \\
\hline Angulitermes sp. & ca,el,ho,sh & $\mathrm{Na}$ & $\mathrm{Sa}$ & $\mathrm{Su}$ & WL & Coaton \& Sheasby, 1972 \\
\hline Angulitermes truncatus & di & $\mathrm{Tz}$ & $\mathrm{Bu}$ & $\mathrm{Su}$ & $\mathrm{L}$ & Kemp, 1955 \\
\hline Anoplotermes sp. & $?$ & $?$ & $?$ & $?$ & $?$ & Weesner, 1970 \\
\hline Cubitermes sp. & ca,el,im,ze & $\mathrm{Na}$ & $\mathrm{Bu}, \mathrm{Sa}$ & $\mathrm{Su}$ & S & Coaton \& Sheasby, 1972 \\
\hline Eremotermes sp. & $?$ & $?$ & $?$ & $?$ & $?$ & Roonwal, 1970 \\
\hline Gnathamitermes tubiformans & $\mathrm{ca}$ & USA & $\mathrm{De}$ & Ex & $\mathrm{L}$ & $\begin{array}{l}\text { Ettershank et al., 1980; } \\
\text { Whitford et al., } 1982\end{array}$ \\
\hline Lepidotermes sp. & ca,el & $\mathrm{Na}$ & $\mathrm{Bu}, \mathrm{Sa}$ & $\mathrm{Su}$ & $\mathrm{S}$ & Coaton \& Sheasby, 1972 \\
\hline Microcerotermes sp. & $\begin{array}{l}\text { bu,ca,do, } \\
\text { el,ho, } \\
\text { hy,ze }\end{array}$ & $\mathrm{Na}, \mathrm{Tz}, \mathrm{Zi}$ & $\mathrm{Bu}, \mathrm{Sa}$ & $\mathrm{Su}$ & W & $\begin{array}{c}\text { Coaton \& Sheasby, } 1972 \\
\text { Kemp, } 1955 \\
\text { Mitchell, } 1980\end{array}$ \\
\hline Microcerotermes cavus & $\mathrm{ca}$ & $\mathrm{Au}$ & $?$ & $\mathrm{Su}$ & W & Ferrar \& Watson, 1970 \\
\hline Microcerotermes distinctus & $\mathrm{ca}$ & $\mathrm{Au}$ & $?$ & $\mathrm{Su}$ & $\mathrm{W}$ & Ferrar \& Watson, 1970 \\
\hline Microcerotermes nervosus & ca & $\mathrm{Au}$ & $?$ & $\mathrm{Su}$ & W & Ferrar \& Watson, 1970 \\
\hline Microcerotermes serratus & ca,ho & $\mathrm{Au}$ & $?$ & $\mathrm{Su}$ & W & Ferrar \& Watson, 1970 \\
\hline Neocapritermes sp. & $?$ & $?$ & $?$ & $?$ & $?$ & Araujo, 1970 \\
\hline Neocapritermes spp. a,b,c & $\mathrm{ca}$ & $\mathrm{Br}$ & $\mathrm{Sa}$ & Ex & $\mathrm{S}$ & DeSouza, 1993 \\
\hline Neocapritermes araguaia & $\mathrm{ca}$ & $\mathrm{Br}$ & $\mathrm{Sa}$ & Ex & $\mathrm{S}$ & DeSouza, 1993 \\
\hline Promirotermes sp. & ca,el,ze & $\mathrm{Na}$ & $\mathrm{Bu}, \mathrm{Sa}$ & $\mathrm{Su}$ & $\mathrm{W}$ & Coaton \& Sheasby, 1972 \\
\hline Synhamitermes sp. & $?$ & $?$ & $?$ & $?$ & $?$ & Araujo, 1970 \\
\hline Termes boultoni & el & $\mathrm{Zi}$ & De & $\mathrm{Su}$ & $\mathrm{W}$ & Mitchell, 1980 \\
\hline
\end{tabular}

